\title{
Evaluation of the psychometric performance of the SCOFF questionnaire in a Mexican young adult sample
}

\author{
Omar Sánchez-Armass, PhD, (1) Flavia Cristina Drumond-Andrade, PhD, ${ }^{(2)}$ Angela R Wiley, PhD, (2) \\ Marcela Raffaelli, PhD, (2) Celia Aradillas-García, PhD, (1) UP AMIGOS 2008 Study Group*
}

\section{Sánchez-Armáss O, Drumond-Andrade FC, Wiley AR, Raffaelli M, Aradillas-García C, UP AMIGOS 2008 Study Group. Evaluation of the psychometric performance of the SCOFF questionnaire in a Mexican young adult sample. Salud Publica Mex 20I2;54:375-382.}

\begin{abstract}
Objective. To examine the psychometric performance of the SCOFF, a brief screening instrument for eating disorders (ED). Materials and methods. Mexican university applicants ( $n=3594,55.7 \%$ female, $M$ age $=$ I8. I years) completed self-report measures and a health screen. Results. Confirmatory factor analyses revealed one factor for females. However a bifactor model fits better for males and females. Reliability was lower for females $(K R 20=.49)$ than males $(K R 20=.59)$. More females (24.2\%) presented risk for ED (SCOFF > 2) than males (II.2\%). Nomological validity indicated that risk for ED in young women was associated with demographic (e.g., parental education), psychological (e.g., depression, weight management efficacy), physical (e.g., BMI), and social (e.g., family conflict) indicators in conceptually coherent ways. Fewer variables were significant for males. Conclusion. Although the SCOFF may be a useful ED screen in Mexico, further research must examine its criterion validity, sensitivity, and specificity.
\end{abstract}

Key words: eating disorders; psychometrics; students; Mexico
Sánchez-Armáss O, Drumond-Andrade FC, Wiley AR, Raffaelli M, Aradillas-García C, UP AMIGOS 2008 Study Group. Evaluación del desempeño psicométrico del cuestionario SCOFF en una muestra de adultos jóvenes mexicanos. Salud Publica Mex 20 I2;54:375-382.

\section{Resumen}

Objetivo. Examinar el desempeño psicométrico del SCOFF, un instrumento de tamizaje para trastornos de conducta alimentaria (TCA). Material y métodos. Aspirantes mexicanos a una universidad $(n=3594,55.7 \%$ mujeres, edad $M=$ I8. I años) completaron cuestionarios y una revisión médica. Resultados. Análisis factoriales confirmatorios revelaron un factor para mujeres, aunque un modelo bifactorial funcionó mejor para hombres y mujeres. La fiabilidad fue menor en mujeres $(K R 20=.49)$ que en hombres $(K R 20=.59)$. Las mujeres $(24.2 \%)$ presentaron mayor riesgo de TCA (SCOFF > 2) que hombres (II.2\%). Validez nomológica indicó que el riesgo de TCA en mujeres jóvenes estuvo asociado con indicadores demográficos (e.g., educación paterna), psicológicos (e.g., depresión, control eficaz de peso), físicos (e.g., IMC), y sociales (e.g., conflicto familiar) de forma conceptualmente coherente. Un subconjunto de estas variables fueron significativas para los hombres. Conclusión. El SCOFF podría ser un tamizaje de TCA útil en México. Sin embargo, se requiere más investigación sobre su validez de criterio, sensibilidad y especificidad.

Palabras clave: trastornos alimenticios; psicometría; estudiantes; México

(I) Facultad de Psicología, Universidad Autónoma de San Luis Potosí. San Luis Potosí, Mexico.

(2) University of Illinois at Urbana-Champaign. Champaign IL, USA.

Study group members: Carmen Rojas, Eduardo Medina Cerda, Esperanza de la Cruz Mendoza, Juan Manuel Vargas Morales (Universidad Autonóma de San Luis Potosí, México) y Margarita Terán García (University of Illinois at Urbana-Champaign, USA).

Received on: May 24, 20II • Accepted on: March 30, 2012

Corresponding author: Dr. Omar Sánchez-Armass. Universidad Autónoma de San Luis Potosí, Facultad de Psicología, Carretera Central Km. 424.5. 78494. San Luis Potosí, México.

E-mail: omarsac@gmail.com 
Tating disorders (ED)-disruptions in normal eating patterns such as self-starvation, unhealthy dieting, or binge/purge cycles-have been reported around the world. ${ }^{1,2}$ Estimates of clinical prevalence rates worldwide range from $0.02-2.2 \%$ for anorexia nervosa (AN) and $0.7-5.4 \%$ for bulimia nervosa $(\mathrm{BN})^{3}$; rates of eating disorder not otherwise specified (EDNOS; a diagnosis for people who meet some criteria for AN or BN) are between $3-5 \% .{ }^{4}$ Although males and females of all ages may be affected by ED, most cases occur in young women. ${ }^{5,6} \mathrm{ED}$ represent a threat to long-term physical and psychosocial well-being. ${ }^{6-8} \mathrm{ED}$ are persistent, with symptoms lasting up to $10-15$ years for $12-14 \%$ of cases, and relapse rates of $4-27 \%$. $^{9}$

ED have been diagnosed primarily in the so-called developed countries, but there is evidence that ED are increasingly common around the world. ${ }^{1}$ There is growing recognition of ED in Mexico, with the prevalence of risky behaviors increasing in students aged 12-19 in Mexico City from 1997 to $2003 .{ }^{10}$ Prevalence rates differ across studies with different samples and measures. ${ }^{9}$ A nationally representative study reported a $\mathrm{BN}$ rate of $0.6 \%$ among men and $1.8 \%$ among females aged 1865 , but no cases of AN. ${ }^{11} \mathrm{~A}$ review of previous studies reported ED related behaviors in 5 - 18\% of Mexican female adolescents, university and high school students. ${ }^{9}$ Given the prevalence and related complications of ED, early detection and effective treatment can decrease severity ${ }^{12}$ and improve prognosis. ${ }^{3}$

One barrier to early ED detection in Mexico is a lack of brief screening tools. A review of Mexican studies highlights disagreement about the instruments used to identify ED. ${ }^{11}$ Common diagnostic tools (e.g., EAT-26 ${ }^{13}$, EDI $^{14}$ ) are too lengthy for primary care settings with large, non-clinical samples considering time, convenience, and cost. ${ }^{15}$ Unikel and colleagues ${ }^{9}$ developed a brief screening instrument for assessing risky eating behaviors for the Mexican population. The 10-item instrument has high reliability and predictive validity, but has only been used in Mexico and Colombia, limiting international comparisons. Furthermore, although relatively brief, its length still may deter use in some settings.

This study focuses on the widely used SCOFF, introduced by Morgan and colleagues as a simple screening tool for ED. ${ }^{16}$ The SCOFF has five questions with good predictive validity. ${ }^{15-18}$ It has been translated and adapted to multiple countries, including Finland, ${ }^{19}$ France, ${ }^{20}$ Italy, ${ }^{21}$ Spain, ${ }^{22}$ China, ${ }^{23}$ Japan,,${ }^{17}$ Korea,${ }^{24}$ Colombia ${ }^{25-26}$ and Israel. ${ }^{27}$ These studies have shown that the SCOFF is a valuable screening tool. We expand on prior work in several ways. First, we examined not only the SCOFF's reliability but also its factor structure with exploratory
(EFA) and confirmatory factor analyses (CFA). Three prior studies examined the SCOFF's factor structure, with inconsistent results. With a Colombian sample, Campo-Arias $\mathrm{et} \mathrm{al}^{28}$ reported a single factor structure for both males and females; Muro-Sans et $\mathrm{al}^{22}$ found a two factor structure for females and a unifactorial solution for males in a Spanish sample. Hautala et a ${ }^{19}$, using CFA to test the one and two factor models in Finland, reported good fit for both, with the two factor structure performing slightly better for females.

Second, we examined the SCOFF's nomological validity (the extent to which it correlates in theoretically predicted ways with measures of related constructs), since the larger study from which our data were derived did not include other eating disorder measures. In these analyses, we evaluated associations between the SCOFF and a set of conceptually-identified factors related to ED in past research. ${ }^{6,29}$ These include indicators of psychological well-being (e.g., depression, ${ }^{30}$ stress, ${ }^{31}$ substance use, ${ }^{7}$ weight-management efficacy, ${ }^{32}$ conflict with parents about weight and health lifestyle, ${ }^{33}$ ) and general health (sedentary behavior and body mass index $\left.[\mathrm{BMI}]^{34}\right)$. To our knowledge, ours is the first study to evaluate the SCOFF in a Mexican sample, representing a potential contribution to future research and practice.

\section{Materials and methods}

\section{Sample}

The sample included 3594 young adults aged 16 to 21 years ( $M$ age $=18.1, S D=1.1 ; 55.6 \%$ female) who applied to the Universidad Autónoma de San Luis Potosí in Mexico in 2008. The larger ongoing project involves annual cross-sectional data collection. The study is Institutional Review Board approved and participants provided written consent. ${ }^{35}$

\section{Measures}

Respondents completed self-report questionnaires and a physical examination. Validated measures were used when available. Other measures were adapted following standard translation/back-translation procedures. This study draws on a subset of measures (Table I).

Demographic characteristics. Respondents reported their gender, age (in years), and highest level of education for either parent.

Disordered eating. The SCOFF ${ }^{16}$ assesses five core aspects of AN and BN (see Table II for items). Each "yes" response is given 1 point, and a total score computed by summing. Scores above 2 are considered a positive 
Table I

Descriptive Statistics Of PARTICIPANTS AT RISK (SCOFF> 2) AND NOT AT RISK (SCOFF $\leq 2$ ) of eating disorders overall and by SeX. San Luis Potosí, MeXico, 2008

\begin{tabular}{|c|c|c|c|c|c|c|}
\hline & \multicolumn{3}{|c|}{ Females } & \multicolumn{3}{|c|}{ Males } \\
\hline & TOTAL & SCOFF $\leq 2$ & SCOFF > 2 & TOTAL & SCOFF $\leq 2$ & SCOFF > 2 \\
\hline & $n=1982$ & $n=1503$ & $n=479$ & $n=1612$ & $n=1431$ & $n=|8|$ \\
\hline \multicolumn{7}{|l|}{ Continuous variables (Mean \pm SD) } \\
\hline Age (years) & $18.0 \pm 1.1$ & $18.0 \pm 1.1$ & $18.0 \pm 1.0$ & $18.2 \pm 1.2$ & $18.2 \pm 1.2$ & $18.3 \pm 1.1$ \\
\hline Depression & $7.3 \pm 5.3$ & $6.4 \pm 4.7$ & $10.0 \pm 5.9 \ddagger$ & $6.1 \pm 4.5$ & $5.9 \pm 4.3$ & $8.0 \pm 5.3 \ddagger$ \\
\hline Stress & $19.8 \pm 6.1$ & $18.6 \pm 5.6$ & $23.6 \pm 6.3 \ddagger$ & $18.0 \pm 5.6$ & $17.5 \pm 5.4$ & $24.6 \pm 5.8 \ddagger$ \\
\hline WEL - Negative emotions & $17.3 \pm 5.6$ & $17.7 \pm 5.6$ & $16.1 \pm 5.5 \ddagger$ & $18.0 \pm 6.1$ & $18.0 \pm 6.2$ & $17.5 \pm 5.5$ \\
\hline WEL - Availability & $15.7 \pm 5.1$ & $16.1 \pm 5.1$ & $14.8 \pm 4.9 \ddagger$ & $16.3 \pm 5.2$ & $16.3 \pm 5.2$ & $15.9 \pm 4.9$ \\
\hline WEL - Social pressure & $16.5 \pm 5.0$ & $16.5 \pm 5.1$ & $16.2 \pm 4.8$ & $16.9 \pm 5.2$ & $17.0 \pm 5.3$ & $16.5 \pm 4.9$ \\
\hline WEL - Physical discomfort & $17.8 \pm 5.3$ & $17.6 \pm 5.4$ & $18.6 \pm 4.9 \ddagger$ & $16.9 \pm 5.7$ & $16.9 \pm 5.8$ & $17.6 \pm 5.3$ \\
\hline WEL - Positive activities & $16.5 \pm 5.2$ & $16.6 \pm 5.3$ & $16.3 \pm 4.8$ & $16.0 \pm 5.8$ & $16.0 \pm 5.9$ & $15.9 \pm 5.2$ \\
\hline Parent-child health conflict & $14.8 \pm 3.5$ & $15.4 \pm 3.1$ & $13.0 \pm 4.1 \ddagger$ & $15.9 \pm 2.7$ & $16.0 \pm 3.4$ & $14.2 \pm 2.5 \ddagger$ \\
\hline Sedentary behavior (hours) & $4.6 \pm 4.4$ & $4.5 \pm 4.6$ & $4.8 \pm 3.8$ & $4.8 \pm 4.6$ & $4.8 \pm 4.8$ & $4.5 \pm 3.2$ \\
\hline BMl (kg/m2) & $23.4 \pm 4.5$ & $23.0 \pm 4.4$ & $24.7 \pm 4.6 \ddagger$ & $23.6 \pm 4.2$ & $23.3 \pm 4.2$ & $25.9 \pm 4.7 \ddagger$ \\
\hline \multicolumn{7}{|l|}{ Categorical variables (percent) } \\
\hline Smoke (\% yes) & 10.5 & 9.2 & $14.8^{\ddagger}$ & 18.8 & 18.1 & 24.3 \\
\hline Drink (\% yes) & 18.9 & 17.8 & $22.3^{*}$ & 35.4 & 35.6 & 33.2 \\
\hline Exercise (\% yes) & 57.2 & 57.0 & 57.8 & 70.7 & 71.5 & $64 . I^{*}$ \\
\hline Parental education - less than bachelor & 74.4 & 72.7 & $79.6^{\ddagger}$ & 71.0 & 71.2 & 69.0 \\
\hline Parental education - bachelor & 25.6 & 27.3 & $20.4^{\ddagger}$ & 29.0 & 28.8 & 31.0 \\
\hline \multicolumn{7}{|c|}{$\begin{array}{l}\text { Note: Significant differences between SCOFF } \leq \text { and }>2 \text { : } \\
* p \leq 0.05 \\
{ }^{\ddagger} p \leq 0.01\end{array}$} \\
\hline
\end{tabular}

screen for AN or BN. ${ }^{16}$ The validated Spanish version of the SCOFF ${ }^{36}$ was used; original wording for all items was preserved.

Psychological well-being. Respondents completed depression, stress, and substance use measures. The CESD-10 ${ }^{37}$ assesses depressive symptoms in the past week with 4 response options from "Rarely or none of the time (less than 1 day)" to "All of the time (5-7 days)." Positive items are reversed and their values ( 0 to 3 ) are summed. The CESD-10 had excellent psychometric properties with Mexican adolescents $\left(\alpha=.93^{38}\right.$; in the current sample $\alpha=.79$ ). Respondents rated their stress in the last month in 6 areas (romantic partner, family, finances, general health, weight, and "other") from $1=$ Not at all to $6=$ Extremely. An overall score was computed by summing $(\alpha=.71)$. There were two dichotomous $(0=$ no, 1 = yes) substance use items: "Do you smoke?" and "Do you drink alcohol?"

Weight-management self-efficacy. The Weight Efficacy Lifestyle Questionnaire (WEL) ${ }^{39}$ assesses self-efficacy in controlling food consumption under five conditions (4 items per domain): negative emotions $(\alpha=.89)$, social pressure $(\alpha=.84)$, availability $(\alpha=.83)$, physical discomfort $(\alpha=.87)$, and positive activities $(\alpha=.82)$. Items are rated from $1=$ Never to $6=$ Always. A score for each domain was computed by summing, with higher scores indicating a higher level of weight management self-efficacy.

Parent-child health conflicts. The Young Adult-Parent Conflicts About Lifestyle (YAPCAL) scale ${ }^{35}$ consists of three items assessing frequency of family conflict due to respondents' health lifestyle (weight, exercise, and eating patterns) on a scale from 1 (Never) to 6 (Always). An overall score was created by summing; higher scores indicate more conflict $(\alpha=.75)$.

Physical activity. A dichotomous item asked "Do you do regular physical activity?" $(0=n o, 1=$ yes $)$. Sedentary behavior was calculated by summing the daily hours participants reported watching television and playing videogames (actual range $=0$ - 14 hours). 
Table II

Item-total corrected point-biserial correlations by SeX. San Luis Potosí, MeXico, 2008

\begin{tabular}{|c|c|c|}
\hline & $\begin{array}{c}\text { Males } \\
r p b i\end{array}$ & $\begin{array}{c}\text { Females } \\
r p b i\end{array}$ \\
\hline $\begin{array}{l}\text { SCOFF I. Do you make yourself sick because you feel uncomfortably full? } \\
\text { (¿Usted se provoca el vómito porque se siente lleno(a)?) }\end{array}$ & 0.18 & 0.23 \\
\hline $\begin{array}{l}\text { SCOFF 2. Do you worry you have lost control over how much you eat? } \\
\text { (iLe preocupa que haya perdido el control sobre la cantidad de comida que ingiere?) }\end{array}$ & 0.27 & 0.37 \\
\hline $\begin{array}{l}\text { SCOFF 3. Do you believe yourself to be fat when others say you are too thin? } \\
\text { (¿Cree que está gordo(a) aunque los demás digan que está demasiado delgado(a)?) }\end{array}$ & 0.16 & 0.09 \\
\hline $\begin{array}{l}\text { SCOFF 4. Have you recently lost more than fourteen pounds in a 3-month period? } \\
\text { (¿Ha perdido recientemente más de } 7 \mathrm{~kg} \text { en un periodo de } 3 \text { meses?) }\end{array}$ & 0.33 & 0.36 \\
\hline $\begin{array}{l}\text { SCOFF 5. Would you say that food dominates your life? } \\
\text { (¿Usted diría que la comida domina su vida?) }\end{array}$ & 0.20 & 0.30 \\
\hline
\end{tabular}

$B M I$. Height was recorded to the nearest 0.5 centimeter and weight to the nearest $0.1 \mathrm{~kg}$ and BMI calculated as $\mathrm{kg} / \mathrm{m}^{2}$. Respondents were classified as underweight (<18.50), normal weight (18.50-24.99), overweight and obese $(\geq 25.0){ }^{40}$

\section{Data analysis}

Data analysis was conducted with R version 2.9. ${ }^{41}$ Significance level was set at $95 \%$ and kept constant across multiple comparisons with Bonferroni's correction. Item-level and factor analyses analyzed psychometric performance. ${ }^{42}$ Point-biserial correlations were calculated to estimate each SCOFF item's discriminatory power. Reliability was assessed with Kuder and Richardson's formula 20 (KR20) and McDonald's omega ( $\omega)$. For the factor analyses, the male and female samples were each randomly split. A principal components exploratory factor analysis (EFA) with promax rotation was used on the first halves; the Very Simple Structure and Velicer MAP criteria were used for factor selection. ${ }^{43}$ On the second halves, maximum likelihood CFA tested previously reported models in the literature (one factor M1 and two factor solution M2, which consisted of Loss of Control Over Food [items 2, 4, and 5] and Purging Behaviors [items 1 and 3])..$^{99,22,28}$

To examine nomological validity, we compared respondents with positive and negative ED screens on the conceptually-identified indicators. Univariate normality and normal distribution of residuals were assessed with the Shapiro-Wilk test. ${ }^{44}$ Residual homogeneity of variance was evaluated with the Brown-Forsythe test. ${ }^{45}$ Group mean comparisons were performed with Student's t-test or Mann-Whitney's U test, depending on normality and homogeneity of variance of residuals.

\section{Results}

Nearly one quarter $(24.2 \%)$ of female respondents, and $11.2 \%$ of male respondents, scored above 2 on the $\mathrm{SCOFF}$, indicating a positive screen for ED. Table I presents the descriptive statistics of participants at risk and not at risk of ED overall and by sex.

\section{Female participants}

Psychometric analyses. The average score on the SCOFF was $0.87(S D=0.99)$. The corrected item-total pointbiserial correlations are presented in Table II. The KaiserMeyer-Olkin measure of sample adequacy test was 0.61 , and Bartlett's test of sphericity was significant, $\chi^{2}(10)=$ $303.7, p<.001$, indicating that the items shared enough common variance to attempt a factor analysis. EFA with 983 participants yielded a unifactorial solution with an eigenvalue of 1.68 (34\% of variance explained). KR20 was $0.49(\omega=0.62)$. Inter-item tetrachoric correlations ranged from 0.04 to 0.58 . Results of the CFA for the second half of female participants $(n=999)$ are presented in Table III. Inter-item tetrachoric correlations ranged from 0.22 to 0.58 . Goodness-of-fit statistics indicated a good fit for both M1 and M2. Reliability for M1 were $\mathrm{KR} 20=.48$ and $\omega=0.49 . \mathrm{KR} 20$ for M2 factors were .48 and .17 respectively, with an $\omega=.61$.

SCOFF Validity. Comparisons of females with positive versus negative screens revealed multiple differences (Table I). Those with positive screens reported higher psychological distress (depressive symptoms, stress, and substance use), lower weight management efficacy in two contexts (when experiencing negative emotions and when food is available), and higher BMI. 
Table III

Confirmatory Factor Analyses for two models of the Scoff. San Luis Potosí, mexico, 2008

\begin{tabular}{|c|c|c|c|c|c|c|}
\hline \multirow{3}{*}{$\begin{array}{l}\text { Sample } \\
\text { Model } \\
\text { Factor }\end{array}$} & \multicolumn{3}{|c|}{ Females $(n=999)$} & \multicolumn{3}{|c|}{ Males $(n=806)$} \\
\hline & \multirow{2}{*}{$\begin{array}{l}\mathrm{MI} \\
\mathrm{FI}\end{array}$} & \multicolumn{2}{|c|}{ M2 } & \multirow{2}{*}{$\begin{array}{c}\mathrm{MI} \\
\mathrm{FI}\end{array}$} & \multicolumn{2}{|c|}{ M2 } \\
\hline & & LCOF & $P B$ & & LCOF & $P B$ \\
\hline Item I & .31 & & .40 & .28 & & .30 \\
\hline Item 2 & .56 & .57 & & .50 & .44 & \\
\hline Item 3 & .18 & & .22 & .25 & & .46 \\
\hline Item 4 & .46 & .46 & & .65 & .53 & \\
\hline Item 5 & .48 & .48 & & .28 & .29 & \\
\hline$r$ & & .73 & & & .45 & \\
\hline$\chi^{2}$ & 7.05 & 5.18 & & 17.27 & 8.54 & \\
\hline df & 5 & 4 & & 5 & 4 & \\
\hline$p$-value & .22 & .27 & & .004 & .07 & \\
\hline$\chi^{2 / d f}$ & 1.41 & 1.29 & & 3.46 & 2.14 & \\
\hline RMSEA & .02 & .017 & & .055 & .038 & \\
\hline AIC & 27.05 & 27.18 & & 37.05 & 30.54 & \\
\hline AGFI & .99 & .99 & & .97 & .98 & \\
\hline
\end{tabular}

Note: RMSEA = root mean square error of approximation; AIC = Akaike's information criterion; $A G F I=$ adjusted goodness of fit index

They endorsed higher weight management efficacy when experiencing physical discomfort and lower levels of health-related conflict with parents. They had less educated parents than those with a negative screen. Being overweight or obese was associated with higher likelihood of endorsing items 1, 2,3 and 5, whereas being underweight was associated with lower likelihood of endorsing items 2,4 and 5 compared to those of normal weight (available upon request).

\section{Male participants}

Psychometric analyses. The average score on the SCOFF was $0.49(S D=0.79)$. Corrected item-total point-biserial correlations are presented in Table II. KMO was 0.62 , and Bartlett's test was significant, $\chi^{2}(10)=200.2, p<.001$. EFA with 806 participants yielded a unifactorial solution with an eigenvalue of 1.64 (33\% of variance explained); KR20 was $0.62(\omega=0.49)$. Inter-item tetrachoric correlations ranged from .10 to .47 . Results of the CFA for the second half of male participants $(n=806)$ are presented in Table III. Goodness-of-fit statistics indicated a good fit only for M2; factor loadings ranged from .30 to .46. Factor reliability coefficients were .40 and .18 , respectively, with an $\omega=.48$.

SCOFF Validity. Males with a positive ED screen had higher levels of depression and stress, higher BMI, and were less likely to exercise than their counterparts (Table I). They reported lower levels of weight and lifestyle conflicts with their parents. The probability of endorsing items 1, 2 and 3 was higher among those with BMI > 25; whereas endorsing items 2 and 4 was lower among underweight than normal weight males (available upon request).

\section{Discussion}

As ED become more common worldwide, effective yet brief screening tools are needed for use across countries. The SCOFF has been used widely to assess ED in developed countries, but its use in Latin America has been limited. ${ }^{25,26,28}$ To our knowledge, ours is the first study to evaluate the SCOFF's psychometric performance in Mexico. We evaluated the internal consistency, factor structure, and nomological validity of the SCOFF in a sample of Mexican young adults. Findings provide information on the utility of the SCOFF as a screening measure in Mexico, and allow identification of future research directions.

The internal consistency of the SCOFF questionnaire was moderately low for both males (KR20 $=.62)$ and females $($ KR20 = .49). Although these internal consistency coefficients are lower than generally deemed desirable, they are similar to those reported in other 
studies (.44 - .58) that concluded the SCOFF is a valuable screening tool..$^{21-23,25,28}$ Only two studies that found lower internal consistencies $(0.2-0.4)$ have concluded that the SCOFF has limited use as a screening instrument. ${ }^{24,26}$ Because the SCOFF is short (just five items) with a simple response format (yes/no) and focuses on diverse behaviors indicative of distinct types of ED, modest reliability estimates are expected. ${ }^{46}$

In terms of factor structure, most studies assume the SCOFF has a unidimensional factor structure. However, two recent studies ${ }^{19,22}$ raise the possibility that the SCOFF may yield two factors reflecting different aspects of ED (control over food vs. purging behavior). Building on this work, we conducted both EFA and CFA on random halves of the male and female samples. EFA indicated only one factor but CFA indicated that a two factor solution may be preferable for males. In EFA, the explained variance for the males $(33 \%)$ was similar to Muro-Sans and colleagues ${ }^{22}(35 \%)$ and Campo-Arias and colleagues ${ }^{28}(35 \%)$. However, explained variance for females (34\%) was lower than they reported in these two studies (55 and 37, respectively). Future testing of the two models is needed to establish clinical utility of the SCOFF in Mexico.

Despite moderate reliability, the SCOFF has shown good predictive validity in studies conducted by the original developers and by other teams. ${ }^{17-22,25,28}$ In analyses to evaluate nomological validity, respondents with positive vs. negative ED screens were found to differ in psychosocial and physical wellbeing, consistent with past research. ${ }^{7,30-33}$ As expected, depression, stress and BMI were higher among both males and females with positive screens. Females with positive ED screens evidenced lower weight management efficacy, except in the presence of physical discomfort when they were more efficacious. This latter association may be related to the nature of ED; for example, those with more ED symptoms may have successfully endured physical discomfort while controlling their intake or purging, thus increasing their efficacy in this realm. Counter to expectation, both males and females with positive screens reported lower levels of lifestyle and weight conflict with parents. This may reflect heightened secrecy and disengagement experienced by young adults with disordered eating. ${ }^{47}$ Taken together, these patterns of association provide preliminary evidence for the nomological validity of the SCOFF in our sample of Mexican young adults. Future studies that evaluate criterion validity (e.g., by comparing the SCOFF to established measures of ED) would provide a stronger test of the SCOFF's utility for use in Mexico.

Although not a central goal of the study, findings confirm that Mexican women are more likely to have ED than men, consistent with gender differences reported in other populations. ${ }^{1,7,29}$ Twice as many females than males had a positive screen for ED (24.2 vs. 11.2\%). The ratio was more balanced than may be expected, given published gender ratios that vary from 2:1 - 4:1 in early adolescence ${ }^{19,48}$ to 10:1 - 20:1 in adulthood ${ }^{29}$; these findings, however, are consistent with other studies involving university students. ${ }^{49,50}$ Prevalence of positive ED screens among female applicants to UASLP were lower than those reported in SCOFF studies conducted in Korea $(34.8 \%)^{24}$ and Colombia $(39.4 \%) .{ }^{25}$ However, rates were considerably higher than reported among 10-19 year olds in the 2006 Mexican National Health and Nutrition Survey $(0.4 \%$ among males and 1.0\% among females); ${ }^{51}$ and in a study of Mexican female university students. ${ }^{52}$ These differences likely reflect variations in age groups, measurement approaches (e.g., use of screeners vs. diagnostic instruments, instrument sensitivity and specificity), and criteria for classifying risk level for ED. Nevertheless, findings are consistent with the 2006 Mexican National Survey on Health and Nutrition, which reported that $17.3 \%$ of adolescent males and $25.8 \%$ of adolescent females reported at least one of the following: worrying about gaining weight, binge eating, loss of control, dieting, fasting, or excessive exercising. Considering the content of the SCOFF items, it is understandable that the rates of risky eating behaviors are similar. ${ }^{53}$

This paper adds to the literature assessing the psychometric performance of the SCOFF in different populations. The study had a number of strengths (e.g., large sample size, multiple correlates of ED). Future research can address study limitations. Established ED measures (e.g., EAT-26, ${ }^{13}$ EDI $^{14}$ ) should be used to assess the SCOFF's criterion validity, specificity and sensitivity in clinical and non-clinical samples. In addition, country-specific research is needed to establish whether the specified SCOFF cut-off of 2 is appropriate for the Mexican context. Finally, future examinations of correlates of the SCOFF should utilize more nuanced and validated measures of health behaviors.

ED are recognized as a growing public health concern in Mexico. Given the potentially serious health consequences of ED, there is a need for brief screening measures for use in general populations. The current study of Mexican college applicants revealed psychometric properties that were largely comparable to published reports from other countries. ${ }^{21-23,25,28}$ Given the inconsistency of some findings, additional examination of the SCOFF's psychometric properties and predictive utility is needed to establish its usefulness as a general screening tool. In the meantime, the use of instruments, such as the Brief Disordered Eating Questionnaire, ${ }^{9}$ 
which has been shown good reliability and predictive validity in Mexican samples, should be used whenever time permits. Ultimately, a better understanding of ED in Mexico could inform the development of health education programs.

Declaration of conflict of interests: The authors declares not to have conflict of interests.

\section{References}

I. World Health Organization (WHO). Prevention of mental disorders: Effective interventions and policy options: Summary report. WHO Department of Mental Health and Substance Abuse. Geneva: WHO, 2004. 2. Hoek H, van Hoek D. Review of the prevalence and incidence of eating disorders. Int J Eat Disord 2003;34:383-396.

3. Perry L, Morgan J, Reid F, Brunton J, O'Brien A, Luck A, et al. Screening for symptoms of eating disorders: Reliability of the SCOFF screening tool with written compared to oral delivery. Int J Eat Disord 2002;32:466-472.

4. Rodríguez B, Oudhof $\mathrm{H}$, González-Arratia N, Unikel-Santoncini C, Becerril MI. Conductas alimentarias de riesgo: Prevalencia en mujeres de nivel superior del Estado de México. ICSA-UAEH 2008;6:I59-I70. 5. Jacobi C, Hayward C, De Zwaan M, Kraemer HC, Agras WS. Coming to terms with risk factors for eating disorders: Application of risk terminology and suggestions for a general taxonomy. Psychol Bull 2004; I30:19-65. 6. Tish Davidson AM. Eating disorders. In: Longe JL, ed. The Gale Encyclopedia of Diets: A Guide to Health and Nutrition. Detroit: Gale, 2008:329-333.

7. Fairburn CG, Harrison PJ. Eating disorders. Lancet 2003;36I:407-4I6. 8. Ruuska J, Koivisto A, Rantanen P, Kaltiala-Heino R. Psychosocial functioning needs attention in adolescent eating disorders. Nord J Psychiatry 2007;61:452-458.

9. Unikel-Santoncini C, Bojórquez-Chapela I, Carreño-García S. Validación de un cuestionario breve para medir conductas alimentarias de riesgo. Salud Publica Mex 2004;46:509-5I5.

I0. Unikel-Santoncini C, Bojórquez-Chapela I, Villatoro-Velazquez J, Fleiz-Bautista C, Medina-Mora ME. Conductas alimentarias de riesgo en población estudiantil del Distrito Federal: Tendencias 1997-2003. Rev Invest Clin 2006;58:15-27.

II. Medina-Mora ME, Borges G, Lara-Muñoz C, Benjel C, Blanco-Jaimes J, Fleiz-Bautista C, et al. Prevalencia de trastornos mentales y uso de servicios: Resultados de la encuesta nacional de epidemiología psiquiátrica en México. Salud Mental 2003;26:1-16.

I2. Parker SC, Lyons J, Bonner J. Eating disorders in graduate students: Exploring the SCOFF questionnaire as a simple screening tool. J Am Coll Health 2005;54:103-107.

13. Garner DM, Olmsted MP, Bohr Y, Garfinkel PE. The Eating Attitudes Test: Psychometric features and clinical correlates. Psychol Med 1982;12:87I-878.

14. Garner DM, Olmstead MP, Polivy J. Development and validation of a multidimensional eating disorder inventory for anorexia nervosa and bulimia. Int J Eat Disord 1983;2:15-34.

I5. Luck AJ, Morgan JF, Reid F, O'Brien A, Brunton J, Price C, et al. The SCOFF questionnaire and clinical interview for eating disorders in general practice: Comparative study. BMJ 2002;325:755-756.

16. Morgan JF, Reid F, Lacey JH. The SCOFF questionnaire: assessment of a new screening tool for eating disorders. BMJ 1999;319:1467-1468. 17. Noma S, Nakai Y, Hamagaki S, Uehara M, Hayashi A, Hayashi T. Comparison between the SCOFF questionnaire and the Eating At- titudes Test in patients with eating disorders. Int J Psychiatry Clin Pract 2006; 10:27-32.

18. Hill LS, Reid F, Morgan JF, Lacey JH. SCOFF, the development of an eating disorder screening questionnaire. Int J Eat Disord 20 10;43:344-35I. 19. Hautala L, Junnila J, Alin J, Gronroos M, Maunula AM, Karukivi M, et al. Uncovering hidden eating disorders using the SCOFF questionnaire: Cross-sectional survey of adolescents and comparison with nurse assessments. Int J Nurs Stud 2009;46: 1439- 1447.

20. Garcia FD, Grigioni S, Chalali S, Meyrignac G, Thibaut F, Dechelotte P. Validation of the French version of SCOFF questionnaire for screening of eating disorders among adults. World J Biol Psychiatry 20 I0; I /:888-893. 21. Siervo M, Boschi V, Papa A, Bellini O, Falconi C. Application of the SCOFF, Eating Attitude Test 26 (EAT 26) and Eating Inventory (TFEQ) Questionnaires in young women seeking diet-therapy. Eat Weight Disord 2005; 10:76-82.

22. Muro-Sans P, Amador-Campos JA, Morgan JF. The SCOFF-c: Psychometric properties of the Catalan version in a Spanish adolescent sample. J Psychosom Res 2008;64;8I-86.

23. Leung SF, Lee KL, Lee SM, Leung SC, Hung WS, Lee WL, et al. Psychometric properties of the SCOFF questionnaire (Chinese version) for screening eating disorders in Hong Kong secondary school students : A cross-sectional study. Int J Nurs Stud 2009;46:239-247.

24. Jung DS, Lee SY, Kim KN, Kand JH. A reliability study of the Korean version of SCOFF (K-SCOFF) Questionnaires. Korean J Obes 2005; 14;108-II3.

25. Rueda-Jaimes GE, Diaz-Martinez LA, Ortiz-Barajas DP, Pinzon-Plata C, Rodriguez-Martinez J, Cadena-Afanador LP. Validación del cuestionario SCOFF para el cribado de los trastornos del comportamiento alimentario en adolescentes escolarizados. Aten Primaria 2005;35:89-94.

26. Campo-Arias A, Cogollo Z, Diaz CE. Cuestionario SCOFF parar tamizaje de trastornos de la conducta alimentaria: Consistencia interna en estudiantes de un colegio de Cartegena, Colombia. Duazary 2007;4:I4-I8. 27. Kaluski DN, Natamba BK, Goldsmith R, Shimony T, Berry EM. Determinants of disordered eating behaviors among Israeli adolescent girls. Eat Disord 2008;16:146-159.

28. Campo-Arias A, Díaz-Martínez LA, Rueda-Jaimes GE, Martínez-Mantilla JA, Amaya-Naranjo W, Campillo HA. Consistencia interna y análisis factorial del cuestionario SCOFF para tamizaje de trastorno de conducta alimentaria en adolescentes estudiantes: Una comparación por género. Univ Psychol 2006;5:295-304.

29. Polivy P, Herman CP. Causes of eating disorders. Annu Rev Psychol 2002;53:187-213.

30. Fox JRE, Power MJ. Eating disorders and multi-level models of emotion: An integrated model. Clin Psychol Psychother 2009;16:240-267. 3I. Pike KM, Wilfley D, Hilbert A, Fairburn GC, Dohm FA, StriegelMoore RH. Antecedent life events of binge eating disorder. Psychiatry Res 2006; 142:19-29.

32. Berman ES. The relationship between eating self-efficacy and eating disorder symptoms in a non-clinical sample. Eating Behav 2006;7:79-90. 33. Pike KM, Hilbert A, Wilfley DE, Fairburn CG, Dohms FA, Walsh BT, et al. Toward an understanding of risk factors for anorexia nervosa: a case-control study. Psychol Med 2008;38: I443-I 453.

34. Fan Y, Li Y, Liu A, Hu X, Ma G, Xu G. Associations between body mass index, weight control concerns and behaviors, and eating disorder symptoms among nonclinical Chinese adolescents. BMC Public Health 2010;10:314-326.

35. Wiley A, Flood T, Andrade FCD, Aradillas-Garcia C, 2009 Up Amigos Study Group. Relationships between the Organization, Climate, and Frequency of Family Mealtimes and Weight Status in Mexico. J Adolesc Health 201 I; 49: 222-224.

36. Garcia-Campayo J, Sanz-Carrillo C, Ibañez JA, Lou S, Solano V, Alda M. Validation of the Spanish version of the SCOFF questionnaire 
for the screening of eating disorders in primary care. J Psychosom Res 2005;59:51-55

37. Kohout FJ, Berkman LF, Evans DA, Cornoni-Huntley J. Two shorter forms of the CES-D (Center for Epidemiological Studies Depression) depression symptoms index.J Aging Health 1993;5: 179-193.

38. González-Forteza C, Jiménez-Tapia JA, Ramos-Lira L, Wagner FA. Aplicación de la Escala de Depresión del Center of Epidemiological Studies en adolescentes de la Ciudad de México. Salud Publica Mex 2008;50:292-299

39. Clark MM, Abrams DB, Niaura RS, Eaton CA, Rossi JS. Self-efficacy in weight management. J Consult Clin Psychol 1991;59:739-744.

40. NHLBI Panel. Identification, Evaluation and Treatment of Overweight and Obesity in Adults. Obes Res 1998;6 suppl 2:1-80.

4I. Ihaka R, Gentleman RR. A language for data analysis and graphics. J Comput Graph Stat 1996;5:299-3।4.

42. Nunnally J, Bernstein I. Psychometric theory. New York: McGraw-Hill Inc, 1994.

43. Revelle W, Rocklin T. Very Simple Structure: An alternative procedure for estimating the optimal number of interpretable factors. Multivariate Behav Res 1979;14:403-4I4.

44. Heiberger RM, Holland B. Statistical analysis and data display: and intermediate course with examples in S-Plus, R, and SAS. New York: Springer, 2004.

45. Brown MB, Forsythe $A B$. Robust tests for the equality of variances. J Am Stat Assoc 1974;69:364-367.

46. Streiner DL. Being inconsistent about consistency: When coefficient alpha does and doesn't matter. J Pers Assess 2003;80:217-222.
47. Knatz S, Maginot T, Story M, Neumark-Sztainer D, Boutelle K. Prevalence rates and psychological predictors of secretive eating in overweight and obese adolescents. Child Obes 201 1;7:30-35.

48. Jáuregui-Lobera I, Romero-Candau J, Bolaños-Ríos P, MontesBerriatúa C, Díaz-Jaramillo R, Montaña-González MT, et al. Conducta alimentaria e imagen corporal en una muestra de adolescentes de Sevilla. Nutri Hosp 2009;24:568-573.

49. Lameiras-Fernández $M$, Calado-Otero $M$, Rodríguez-Castro $Y$, Fernández-Prieto M. Los trastornos de la conducta alimentaria en estudiantes universitarios españoles. Actas Esp Psiquiatr 2002;30:343-349. 50. Saucedo-Molina TJ, Unikel-Santoncini C. Conductas alimentarias de riesgo, interiorización del ideal estético de delgadez e índice de masa corporal en estudiantes hidalguenses de preparatoria y licenciatura de una institución privada. Salud Mental 2010;33:1-19.

5I. Barriguete-Meléndez JA, Unikel-Santoncini C, Aguilar-Salinas C, Córdoba-Villalobos JA, Shamah T, Barquera S, et al. Prevalence of abnormal eating behaviors in adolescents in Mexico: Mexican national health and nutrition survey 2006. Salud Publica Mex 2009:5I:638-644.

52. Mancilla JM, Alvarez G, López X, Mercado L, Manríquez E, Román M. Trastornos alimentarios y factores asociados en universitarias mexicanas. Psicol Cienc Soc 1998;2:34-58.

53. Olaiz-Fernández G, Rivera-Dommarco J, Shamah-Levy T, Rojas R, Villalpando-Hernández S, Hernández-Ávila M, et al, eds. Encuesta Nacional de Salud y Nutrición 2006. Cuernavaca, México: Instituto Nacional de Salud Pública, 2006. 